\title{
DETERMINATION OF CUSTOMER APPAREL PREFERENCES BY USING LATENT CLASS ANALYSIS: AN APPLICATION FOR KOTON BRAND*
}

\author{
Ph.D. Merve DOĞRUEL ANUŞLU \\ Istanbul Gedik University, Faculty of Engineering, Turkey (merve.anuslu@gedik.edu.tr) \\ Prof. Çiğdem ARICIGIL ÇİLAN \\ Istanbul University, School of Business Administration, Turkey (ccilan@istanbul.edu.tr)
}

\begin{abstract}
In the Fast Fashion sector, identifying the fashion orientation and lifestyle of their customers provides an enterprise the understanding of the needs and desires of their customers alongside helping the implementation of appropriate marketing strategies and achieving upper hand in the competition. In this study, it is aimed to classify their preferences regarding the fashion orientation and lifestyle of their female customers to develop marketing strategies for KOTON, a fast fashion company operating in Turkey as well as globally. For this purpose, Latent Class Analysis was applied as an analytical method and appropriate marketing strategies were suggested for each class.
\end{abstract}

Keywords: Latent Class Analysis, Customer Segmentation, Fast Fashion, Fashion Orientation, Lifestyle.

\section{GÖZLENEMEYEN SINIF ANALIZİ KULLANILARAK MÜŞTERİ GIYIM TERCIHLERININ BELIRLENMESI: KOTON MARKASI IÇIIN BİR UYGULAMA}

\begin{abstract}
ÖZET
Hızl moda sektöründe işletmenin müşterilerinin moda yönelimlerini ve yaşam tarzlarını belirlemesi; müşterilerinin ihtiyaç ve isteklerini anlamasını sağlamakla birlikte, uygun pazarlama faaliyetleri uygulamasında ve markasının rekabet üstünlüğ̈̈ sağlamasında yardımcı olmaktadır. Bu çalışmada Türkiye ve dünyada faaliyet gösteren hızlı moda şirketi olan KOTON'un kadın müşterilerinin moda yönelimi ve yaşam tarzına göre tercihlerini sinfflandirarak, oluşan sinıflara uygun pazarlama stratejileri geliştirilmesi hedeflenmektedir. Bu amaçla Gözlenemeyen Sınıf Analizi, analiz yöntemi olarak uygulanmış ve her bir sinıf için uygun pazarlama stratejileri önerilmiştir.
\end{abstract}

Anahtar Kelimeler: Gözlenemeyen Sınıf Analizi, Müşteri Bölümlendirme, Hızlı Moda, Moda Yönelimi, Yaşam Tarzı.

\footnotetext{
* This article was created from the Ph.D. thesis of Merve Doğruel Anuşlu. This work was supported by Scientific Research Projects Coordination Unit of Istanbul University. Project number 36726.
}

www.ijmeb.org ISSN:2147-9208 E-ISSN:2147-9194

http://dx.doi.org/10.17130/ijmeb.2019252110

Received: 18.03.2017, Accepted: 28.11.2018

542
ORCID ID:

Merve DOĞRUEL ANUŞLU 0000-0003-2299-7182

Çiğdem ARICIGILl ÇİLAN 0000-0002-7862-7028 


\section{Introduction}

Fashion is a very broad concept. Among many factors in fashion, the segment of clothing holds a special place. It emerged as vital need after physiological needs (Jones, 2009, Watson, 2007). Sociologically, the appearances of people in clothes and accessories seem to influence the society's thought and individual's behaviors. Therefore, fashion should be considered as a lifestyle in addition to clothing (Tungate, 2006).

Fast Fashion is described by Byun and Sternquist (Byun \& Sternquist, 2008) as "a marketing approach to responding to the latest fashion trends by frequently updating products with a short renewal cycle and turning the inventory at a rapid rate." Fast fashion is considered to be the "supermarket" segment of the fashion market in the true sense.

It is known that consumers will manage the market in the 21st century. Consumers display the power of spending in a market, thereby influencing the success of brands in that marketplace. It is therefore very important for brands to understand customers in order to survive and to be profitable in the highly competitive and rapidly changing 21 st century (Preez, 2003).

Variables that determine purchasing behavior in fast fashion retailing can be classified in three groups as customer-driven, market-driven and customer and market interactive-driven variables (Preez, 2003). Fashion orientation and lifestyle concepts are within the customerdriven variables, one of the main topics that affect the purchasing behavior.

Latent Class Analysis is a technique for analyzing relationships in categorical data; This is the relationship between the variables at the nominal or ordinal measurement level. The aim of the LCA is to classify participants according to the underlying latent typological structure using discrete variables selected as observed variables. Researchers are expected to find the minimum number of classes defined by the relationship between the selected variables (Arıcigil Ç., 2014).

Applications of Latent Class Analysis have been widely used in the field of Social Sciences. However, in the literature, it has not seen that Latent Class Analysis is applied for fast fashion segmentation yet.

Customer segmentation to be implemented in determining the preferences of female customers of KOTON brand which operates in fast fashion retailing in Turkey and overseas will be performed by the Latent Class Analysis, one of the advanced categorical data analysis methods.

In this study, classification by the fashion orientation and lifestyle of the customers aiming to identify the purchasing behavior and preferences of the female customers of the KOTON brand. For this purpose, it is aimed to identify the classes by applying Latent Class Analysis and develop appropriate marketing strategies for the identified classes, by gathering data from the female customers of KOTON through a survey. 


\section{Fashion Orientation}

Gutman and Mills have described fashion orientation as for how an individual determines his / her clothes about the evaluation of other people (Gutman \& Mills, 1982). The fashion orientation is measured in four dimensions as fashion leadership, fashion interest, the importance of being the well-dressed and anti-fashion attitude. The fashion orientation scale was created by Gutman and Mills in 1982, proving its use and reliability in identifying individual characteristics that affect customer behaviors (Zarley, 2010).

The expressions to measure fashion leadership, fashion interest, the importance of being well-dressed and anti-fashion attitude are as follows (Gutman \& Mills, 1982):

\section{Fashion Leadership}

- It is important for me to be a fashion leader.

- I am confident in my ability to recognize fashion trends.

- I want to be one of the first to try fashion trend.

- I am the first to try new fashion; therefore, many people regard me as being a fashion leader.

- Clothes are one of the most important ways I have of expressing my individuality.

\section{Fashion Interest}

- Because if my active lifestyle, I need a wide variety of clothes.

- I always buy at least one outfit in the latest fashion.

- I always read fashion magazines/blogs.

- I spend a lot of time on fashion-related activities.

\section{Importance of Being Well-dressed}

- It's important to be well-dressed.

- If you want to get ahead, you have to dress the part.

- What you think of yourself is reflected in what you wear.

- Wearing good clothes is part of leading the good life.

\section{Anti-fashion Attitude}

- I resent being told what to wear by so-called fashion experts.

- The fast fashion clothing is just a way to get more money from the consumer.

- I buy clothes I like regardless of the current fashion. 


\section{Lifestyle}

While Hawkins et al. (Hawkins et al., 2010) describe lifestyle as "simply how humans live"; Preez, Visser and Zietsman (Preez et al., 2007) state that lifestyle can be affected by family, friends, and communication. Hoyer and Macinnis (Hoyer \& Macinnis, 2009) define lifestyle as the actual models of the behaviors representing the activities, interests, and thoughts of the customers. In many academic studies, lifestyle is often associated with customers' preferences and/or choices. Customers with different thoughts and interests will behave differently in shopping as well.

The main lifestyle measures are listed below (Yeşiloğlu, 2013).

- Values and Lifestyles (VALS / VALS 2)

- Rokeach Value Survey

- List of Values (LOV)

- Prism (Geo-Lifestyle)

- FIF (Activities, Interests, Ideas)

The Stanford Research Institute (SRI) proposed the VALS scale in 1978 and the new VALS scale (VALS2) in 1989 concerning Arnold Mitchell's study.Among all these measurement methods, VALS 2 scale is one of the most widespread psychographic segmentation methods and based on the hierarchy of needs of Abraham Maslow (Hamşığlu, 2013). The VALS 2 scale was developed to explain not only what consumers buy, but also why they buy and how they make decisions. The main determinants of this scale are psychological characteristics and personalities (Yeşiloğlu, 2013).

VALS 2 customer types are as follows: ${ }^{1}$

Innovators: Successful and sophisticated. They manage people with their high selfconfidence. They are the leaders of the innovations, open to new ideas and technologies. They purchase luxury-niche products.

Thinkers: Mature, satisfactory, peaceful and considerate. They tend to be well educated and do active research during the decision process. They care about the durability, functionality and the overall value of the product.

Believers: Extremely traditional, stuck to the rules and authoritarian. Because essentially, they are conservative, they respond changes slowly and don't like technology. They choose familiar products and established brands.

Achievers: They have goal-oriented lifestyles that are centered on their families and careers. They avoid change. They prefer showing successful and quality products to their peers.

1 Online, http://www.strategicbusinessinsights.com/vals/free/2010-06-VALSbrochure.pdf, 30th March 2015 
Strivers: They are trendy and fun loving. They have lesser income by preference, and they tend to have restricted interests. They prefer products imitating the purchases of more well-off people. Most slaves believe that the life is unfair.

Experiencers: They like being extraordinary. They are active and driven by their impulses. They feed on the new and the extraordinary. They take the risk. They allocate a significant portion of their income for fashion, socializing and entertainment.

Makers: Practicality and self-sufficiency are important for the makers. They prefer applied improving researchers; they spend their spare time with their families and close friends. They prefer value over luxury and purchase essential products.

Survivors: They barely survive. They have quite limited resources. Usually, they do not look willing and often feel powerless. Security and safety are their priorities, so they tend to be loyal to brands and buy from discount.

\section{Fashion Orientation and Lifestyle in Apparel Purchasing Behavior}

The fashion orientation scale created by Gutman and Mills has proven to be both reliable and useful to determine the individual characteristics affecting consumption behavior (Gam, 2011; Park \& Buns, 2005; Darley \& Johnson, 1993). Gam (2011) researched that whether fashion and shopping orientation are determinants of environmentally friendly clothing purchase intention. The findings from a series of linear regression analyses indicated that fashion orientation factor (together with other two factors) are significantly related to consumers' purchase intention regarding environmentally friendly clothing. Park and Buns (2005) investigated that relationship between fashion orientation and the credit cards and found that fashion interest significantly influenced compulsive buying directly and also indirectly by influencing credit card use. Darley and Johnson (1993), examinated the effects of female adolescent locus of control on attitudes towards shopping, fashion orientation and knowledge research in the United States and found that American female adolescents' shopping behaviors were influenced by fashion orientation.

The different forms of lifestyle groups that are affected by the factors such as the values of the consumers, their past experiences, personalities, emotions, social classes, cultures, etc., mean that consumer behaviors are different (Odabaşı \& Barış, 2003). In many studies in the literature, it has been shown that lifestyle based on psychographic affects and reflects consumer behavior. $\mathrm{Wu}$ found that $(\mathrm{Wu}, 2013)$ the attitude toward online shopping has a significant relationship with the consumer lifestyle. Harps and others (Harp, Hlavaty \& Horridge, 2000) used Discriminant analysis after MANOVA test on store attributes, apparel purchase influences, and lifestyle characteristics. One of the findings of this study was the effect of lifestyle in South Korean women shoppers' apparel shopping orientation. See among others Zietsman, 2006; Shim \& Kotsiopulos, 1993; Cassill \& Drake, 1987.

It is known that the manufacturers in the fashion industry are well aware of customers' lifestyles and are working to make collections accordingly. In a study conducted with 816 customers in 2010 (Jina, 2010), a direct relationship was found between fashion orientation and lifestyles of luxury brand customers in Japan and Korea. In this study, the concepts of fashion 
orientation and lifestyle, which are two psychographic variables affecting apparel purchasing behaviors, have been evaluated together to identify their preferences. In the clustering study of apparel buying behavior, Preez and Visser (Preez \& Visser, 2003) showed that two of the variables affecting the cluster was lifestyle and fashion orientation.

In the academic studies, consumers' opinions on fashion orientation and their lifestyles were found to be influential on customers' apparel purchasing behavior. These two concepts need to be analyzed in order to well understand the behavior of customers and to carry out marketing activities effectively. In this study, fashion orientation and lifestyle will be used together in the analysis of the customers' apparel segmentation.

\section{Latent Class Analysis}

Direct measurements of variables in social sciences are not easy to do. For example; customer satisfaction in Marketing, life satisfaction in Sociology or level of intelligence in Psychology cannot be measured directly. Two or more observed variables are used to represent these variables that are not directly measured. These variables, which cannot be observed directly, are called latent variables. The latent term is regarded as an error-free non-observed variable. Observed variables include errors while latent variables contain no errors. Observed variables are also called indicators of latent variables (Collins \& Lanza, 2010).

Latent variable models can be examined in four main groups in Table 1 according to the distributions of observed and latent variables (Bartholomew et al., 2011).

Table 1: Four Main Classifications of Latent Variable

\begin{tabular}{lcc}
\hline & \multicolumn{2}{c}{ Latent Variable(s) } \\
\cline { 2 - 3 } Observed Variables & Continuous & Categorical \\
\hline Continuous & Factor analysis & Latent profile analysis \\
\hline Categorical & Latent feature analysis & Latent class analysis \\
\hline
\end{tabular}

Latent Class Analysis is often used to investigate observed measurements that are categorically highly correlated with each other. Latent Class Analysis is considered as a nonparametric alternative to Factor Analysis.

Exploratory Latent Class Analysis is used to reveal latent structures among the observed variables in the research while Confirmatory Latent Class Analysis is used to test the latent structures among the observed variables. While there is no constraint on parameters in Explanatory Latent Class Analysis, there are various constraints on parameters in Confirmatory Class Analysis.

Latent Class Analysis is a method used to analyze the relationships of categorical data. The main rationale for Latent Class Analysis is that the data is partly analyzed based on contingency tables (McCutcheon, 1987).

In the contingency tables, the interpretations of the relations are made in two ways, with and without causality. Model predictions are made based on tables to make causal 
interpretations. Models are not needed for interpretations without causality. Rosenberg described the non-causal interpretation as a symmetrical relationship. (McCutcheon, 1987) The Basic Latent Class Analysis focuses on symmetrical relationships, and there is no causal relationship in it.

Latent Class Models are based on local independence assumption as in all latent models (such as Factor Analysis, Structural Equation Models, Latent Feature Analysis) (McCutcheon \& Mills, 1998). In latent models; the observed variables that are related to each other become independent from each other when the latent variable is taken into account, which means that the correlation between them disappears. (Hagenaars, 1993). This feature is called "local independence" and is considered the most basic assumption of latent models. Independence is only for each latent class, so it is called local (Collins \& Lanza, 2010).

The Latent Class Model for the four observed variables (A, B, C, D) and a latent variable of T category (X) can be defined as follows (Hagenaars, 1993):

$$
\pi_{\mathrm{ijklt}}^{\mathrm{ABCDX}}=\pi_{\mathrm{t}}^{\mathrm{X}} \pi_{\mathrm{ijklt}}^{\overline{A B C D X}}=\pi_{\mathrm{t}}^{\mathrm{X}} \pi_{\mathrm{it}}^{\overline{A X}} \pi_{\mathrm{jt}}^{\overline{B X}} \pi_{\mathrm{kt}}^{\overline{C X}} \pi_{\mathrm{ilt}}^{\overline{D X}}
$$

$\pi_{\mathrm{t}}^{\mathrm{X}}$ is the marginal probability of the $\mathrm{t}$ class of the $\mathrm{X}$ latent variable. $\pi_{\mathrm{ijklt}}^{\overline{A B C D X}}$, is a conditional probability of joint $\mathrm{A}, \mathrm{B}, \mathrm{C}, \mathrm{D}$ observed variables when $\mathrm{X}=\mathrm{t} . \pi_{\mathrm{it}}^{\overline{A X}}$, the latent variable is a conditional probability for $\mathrm{A}=\mathrm{i}$ when class $\mathrm{t}$ is given to $\mathrm{X} . \pi_{\mathrm{jt}}^{\bar{B} \mathrm{X}}, \pi_{\mathrm{kt}}^{\overline{C X}}, \pi_{\mathrm{lt}}^{\overline{D X}}$ probabilities, when $\mathrm{X}=\mathrm{t}$, are conditional probabilities for $\mathrm{B}=\mathrm{j}, \mathrm{C}=\mathrm{k}$, ve $\mathrm{D}=\mathrm{l}$ categories respectively.

The magnitudes of the latent class probabilities indicate if the population is distributed in a balanced manner among $\mathrm{T}$ class, or that some of the latent class represent relatively bigger parts of the population while other classes represent the lesser parts. Overall T latent classes, the sum of latent class probabilities $\pi_{\mathrm{t}}^{\mathrm{X}}$ must equal 1 (Neves \& Fonseca, 2015).

$$
\sum_{t} \pi_{\mathrm{t}}^{\mathrm{x}}=1
$$

There is (T-1) possibility of a latent class to be estimated (Arıcıgil Ç., 2014). Since the observed variables can be two or multiple categories, the number of conditional probabilities for each of the observed variables equals the number of categories of the variable in question. For example, each class $\mathrm{T}$ of the latent variable $\mathrm{X}$ has $(\mathrm{I}+\mathrm{J}+\mathrm{K}+\mathrm{L})$ conditional probability when it has 4 observed variables of I, J, K, and L categories. The sum of the conditional probabilities of the observed variable in each class T must equal 1 (McCutcheon, 1987).

$$
\sum_{i} \pi_{\mathrm{it}}^{\bar{A} \mathrm{X}}=\sum_{j} \pi_{\mathrm{jt}}^{\bar{B} \mathrm{X}}=\sum_{k} \pi_{\mathrm{kt}}^{\bar{C} \mathrm{X}}=\sum_{l} \pi_{\mathrm{lt}}^{\bar{D} \mathrm{X}}=1
$$

We need the estimation of $(\mathrm{I}-1)+(\mathrm{J}-1)+(\mathrm{K}-1)+(\mathrm{L}-1)$ conditional probability for each of the (T) latent classes in a model of four observed variables with I, J, K and L categories (Arıcıgil Ç., 2014). 
Likelihood ratio chi-squared statistic $(\mathrm{G})$ is widely used to assess the fit of Latent Class models (McCutheon, 2002):

$$
\mathrm{G}^{2}=2 \sum_{\mathrm{ijkl}} \mathrm{F}_{\mathrm{ijkl}} \ln \left(\mathrm{F}_{\mathrm{ijkl}} / \widehat{F}_{\mathrm{ijkl}}\right)
$$

To test the model, Chi-Squared distribution in the following degree of freedom is employed (Goodman, 1974).

$$
\begin{aligned}
\text { d.f. } & =\mathrm{IJKL}-1-\{\mathrm{T}(\mathrm{I}+\mathrm{J}+\mathrm{K}+\mathrm{L}-3)-1\} \\
& =\mathbf{I J K L}-\mathbf{T}(\mathbf{I}+\mathbf{J}+\mathbf{K}+\mathbf{L}-\mathbf{3})
\end{aligned}
$$

The estimated model can be tested only when the degree of freedom is positive (McCutheon, 1987).

The number of parameters (M) that should be estimated in a latent class model with 4 observed variables of I, J, K, and L categories is as follows (Goodman, 1974):

$$
\begin{aligned}
\mathrm{M} & =(\mathrm{T}-1)+\mathrm{T}[(\mathrm{I}-1)+(\mathrm{J}-1)+(\mathrm{K}-1)+(\mathrm{L}-1)] \\
& =\mathrm{T}(\mathrm{I}+\mathrm{J}+\mathrm{K}+\mathrm{L}-3)-1
\end{aligned}
$$

In Multi-Group Latent Class Analysis, in addition to the latent and observed variables of the Latent Class Analysis, there is also group variable(s) which are observed variables. The model with four observed variables (A, B, C, D), one latent variable $(\mathrm{X})$ and one group variable which is observable variable $(\mathrm{G})$ is written as follows (Vermunt, 1996):

$$
\pi_{\mathrm{ijklts}}^{A B C D G}=\pi_{\mathrm{s}}^{\mathrm{G}} \pi_{\mathrm{ts}}^{\bar{X} \mathrm{G}} \pi_{\mathrm{its}}^{\bar{A} X \mathrm{G}} \pi_{\mathrm{jts}}^{\bar{B} X \mathrm{G}} \pi_{\mathrm{kts}}^{\bar{C} X \mathrm{G}} \pi_{\mathrm{lts}}^{\bar{D} X \mathrm{G}}
$$

The constraints of the model are as follows (Kankaraš, 2010):

$$
\sum_{\mathrm{t}} \pi_{\mathrm{ts}}^{\mathrm{XG}}=\sum_{\mathrm{i}} \pi_{\mathrm{its}}^{\overline{A X G}}=\sum_{\mathrm{j}} \pi_{\mathrm{jts}}^{\bar{B} \mathrm{XG}}=\sum_{\mathrm{k}} \pi_{\mathrm{kts}}^{\overline{C X G}}=\sum_{\mathrm{l}} \pi_{\mathrm{lts}}^{\overline{D X G}}=1
$$

When the number of observed variables and/or the number of categories of these variables is large, many cells in the contingency table may remain empty. The Chi-squared distribution should not be used to calculate $\mathrm{p}$ because likelihood ratio chi-squared statistic $\left(\mathrm{G}^{2}\right)$ the cannot sufficiently converge to the Chi-Squared distribution when many cells in the contingency table are empty (when sparse data is available). Instead, Bootstrap approaches can be employed to compute $\mathrm{p}$. In this case, the Information Criteria, which is one of the alternative convenience measures, can be employed in evaluating the model convenience. The most frequently used information criterion in Latent Class Analysis is the Bayesian Information Criterion (BIC) (Magidson \& Vermunt, 2004). The formula of BIC is as the following (McCutheon, 2002):

$$
\begin{aligned}
\mathrm{BIC} & =\mathrm{G}^{2}-\text { d.f. } *[\ln (\mathrm{N})] \\
\mathrm{N} & =\sum_{\mathrm{i}}^{1} \sum_{\mathrm{j}}^{\mathrm{J}} \sum_{\mathrm{k}}^{\mathrm{K}} \sum_{\mathrm{l}}^{\mathrm{L}} \mathrm{F}_{\mathrm{ijkl}}
\end{aligned}
$$




\section{Research and Sample Design}

In this study, it is aimed to classify their preferences regarding the fashion orientation and lifestyle of their female customers to develop marketing strategies for KOTON, a fast fashion company operating in Turkey as well as globally. Multi-Group Latent Class Analysis was used as an application method, and Latent Gold 5.1 Program was used for analysis application.

\section{Figure 1: Latent Class Model for the Application}

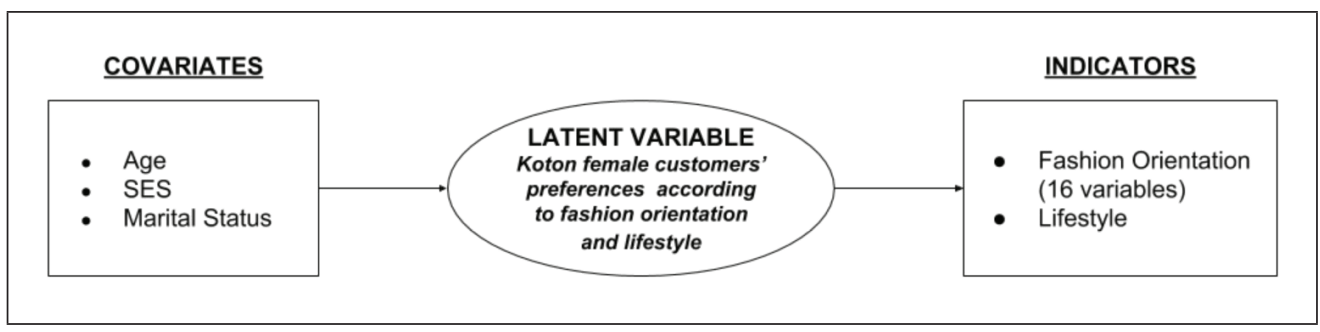

As seen in Figure 1, the preference of KOTON female customers according to their fashion orientation and lifestyle is determined as a latent variable. The demographic variables (age, socioeconomic status, and marital status) included in the model are the covariates of the model. Because of the local independence assumption, it is not necessary to explain the relationships between demographic variables (age, socioeconomic status and marital status) by latent classes. For this reason, these variables are covariates in the model. The fashion orientation and lifestyle variables will be included in the analysis of observed variables. To identify the lifestyles of female customers, customer responses to the VALS 2 scale, consisting of 41 questions, were entered ${ }^{2}$ into the website and one of 8 different lifestyles was identified for each client. When the Latent Class Analysis is applied, the lifestyle determined for each female client have been included as an observed variable in the analysis.

In determining the sample size, the criteria in Table 2 were taken as reference (Walker \& Almond, 2010).

Table 2: Suggested Sample Sizes for Continuous and Categorical Variables by Number of Population Units

\begin{tabular}{lcc}
\hline \multirow{2}{*}{ Number of Population Units (n) } & \multicolumn{2}{c}{ Significance Level $(\boldsymbol{\alpha}) \mathbf{5 \%}$} \\
\cline { 2 - 3 } & Continuous Variable & Categorical Variable \\
\hline 100 & 55 & 80 \\
\hline 500 & 96 & 218 \\
\hline 1000 & 106 & 278 \\
\hline $4000+$ & 120 & 400 \\
\hline
\end{tabular}

The number of the customers of KOTON brand is over 4000. According to Table 2, sample size should be at least 400. It was targeted to work with 500 customers in the research.

2 Online, http://www.strategicbusinessinsights.com/vals/surveynew.shtml, 7th May 2015 
The data were collected by applying a questionnaire. During determining the stores to survey, by considering the customer profile determined in the previous researches of KOTON brand, a total of 5 stores have been selected for the survey including 1 store (A) with dominant customers from A SES group, 1 store (B) with dominant customers from A-B SES group, 2 stores (C and D) with dominant customers from B-C1 SES group and 1 store (E) with dominant customers from C1-C2 SES group. Based on the distribution of KOTON's registered customer profile, it was targeted to reach a total of 500 people, 50 from A, 55 from B, 170 from $\mathrm{C}, 175$ from $\mathrm{E}$ and 50 from $\mathrm{E}$. Using the door counters of the 5 identified stores, the average number of customer visits per store have been identified for each of them. The aim of systematic sampling is to show that the average number of customers per day for each store $\mathrm{N}_{\mathrm{i}}$ is compared $\left(\frac{\mathrm{N}_{\mathrm{i}}}{\mathrm{n}_{\mathrm{i}}}=\mathrm{k}_{\mathrm{i}}\right)(\mathrm{i}=1,2, . ., 5)$ to the number of samples to be selected $\left(\mathrm{n}_{\mathrm{i}}\right)$, and it has been observed that the $k_{i}$ value of each store is similar to all stores so $k_{i}$ is set as 10 . For this reason, the addition of $\mathrm{k}_{\mathrm{i}}=10$ has been made to the random value chosen between 1 and $k_{i}$ and one in every 10 female customers at the cashiers. The survey has been conducted with females between the ages 16-50, who approved to participate in the survey. 453 valid questionnaires have been acquired after 7 days of work. (The survey has been conducted during a low discount period in KOTON brand.)

There are 17 observed variables affiliated with 16 fashion orientation and 1 lifestyle, and 3 covariates, a total of 20 variables in the model (Appendix 1). All variables are nominal scale. The possible number of results expected from the model is $2^{16} \times 8 \times 5 \times 4^{2}=41,943,040$ , since all of the variables affiliated to the fashion orientation consist of 2 categories, lifestyle variables consist of 8 categories, age variables consist of 5 categories, SES variables consist of 4 categories, and marital status variables consist of 4 categories. In applying Latent Class Analysis with 20 variables, it was predicted that most of the cells in the multidimensional contingency table were empty. When the model was applied, it was concluded that the number of cells is found to be 6,783. There are several empty cells in the model. For this reason, the BIC was used instead of the frequently used $\mathrm{G}^{2}$ statistics as the eligibility criterion in assessing the suitability of the model.

The analysis has been initiated by estimating latent class models including 1,2,3,4 and 5 latent classes with 17 observable variables and 3 covariates. The model with the lowest BIC value among the tested models was selected as the most suitable model.

It should be tested whether the variable parameters of the selected models differ according to the classes. Test hypotheses are as follows:

$$
\begin{aligned}
& \mathrm{H}_{0}: \lambda_{\mathrm{i} 1}^{\mathrm{AX}}=\lambda_{\mathrm{i} 2}^{\mathrm{AX}}=\ldots=\lambda_{\mathrm{iT}}^{\mathrm{AX}} \quad \mathrm{i}=1,2, \ldots, \mathrm{I} \\
& \mathrm{H}_{1}: \text { At least one is different. }
\end{aligned}
$$

I represents the number of observed variables and $\mathrm{T}$ represents the number of classes.

Walt Test is employed for testing the hypotheses. When the variables that do not make a meaningful a meaningful difference between the classes $(p>0.05)$ were dismissed from the analysis one by one, the latent class models were tried again with 1, 2, 3, 4 and 5 class models and the same process was repeated until all the parameters make sense. 
The variables dismissed from the analysis since they do not meaningful difference are SES, "it is unnecessary to me to be said what to wear by people called fashion experts" and the marital status.

The research model, when evaluated in terms of both the BIC and the significance of the variables, was selected as a 4-class model in which 15 fashion orientation, 1 lifestyle and 1 age covariate were included (Table 3).

Table 3: Latent Model Estimates with 16 Observed Variables and 1 Covariates

\begin{tabular}{cccccccc}
\hline & LL & BIC (LL) & $\begin{array}{c}\text { Num. of } \\
\text { Par. }\end{array}$ & L2 & Df & p-value & $\begin{array}{c}\text { Class } \\
\text { Error }\end{array}$ \\
\hline Class 1 & -4823.6133 & 9775.6603 & 21 & 5623.9827 & 432 & $4,7 \mathrm{e}-890$ & 0 \\
\hline Class 2 & -4581.1057 & 9449.6583 & 47 & 5138.9674 & 406 & $2,5 \mathrm{e}-807$ & 0.0683 \\
\hline Class 3 & -4435.8499 & 9318.1599 & 73 & 4848.4559 & 380 & $1,5 \mathrm{e}-763$ & 0.0567 \\
\hline Class 4 & -4329.7192 & 9264.9116 & 99 & 4636.1944 & 354 & $1,8 \mathrm{e}-735$ & 0.0656 \\
\hline Class 5 & -4264.5547 & 9293.5958 & 125 & 4505.8654 & 328 & $6,2 \mathrm{e}-724$ & 0.0756 \\
\hline
\end{tabular}

\section{Results}

According to the BIC and the 4-class model that is most appropriate in terms of the significance of the variants, the female customers of KOTON are divided into four categories according to their fashion orientation and lifestyle preferences:

Table 4: Latent Class Probabilities According to the Fashion Orientation and Lifestyle Preferences of the Female Customers of KOTON

\begin{tabular}{lcccc}
\hline & Class 1 & Class 2 & Class 3 & Class 4 \\
\hline Size of the Class & 0.4080 & 0.2471 & 0.2355 & 0.1094 \\
\hline
\end{tabular}

Probabilities of latent class are obtained as $\widehat{\mathrm{n}}_{1}^{\mathrm{x}}=0.4080, \widehat{\mathrm{n}}_{2}^{\mathrm{x}}=0.2471, \widehat{\mathrm{n}}_{3}^{\mathrm{x}}=0.2355$, $\widehat{\mathrm{n}}_{4}^{\mathrm{x}}=0.1094$. The probability for female customers of KOTON for the 1 st class is $40 \%$, the 2 nd class is $25 \%$, the 3 rd class is $24 \%$, and the 4 th class is $11 \%$. It is observed that approximately $65 \%$ of female customers who opt for the KOTON Brand are in the 1st and 2nd class. Accordingly, it can be said that it is important for the KOTON Brand to develop marketing strategies for the first and second classes in order to satisfy their customer base.

When all the conditional probability tables of observed variables and covariates are examined, it is possible to make the following interpretations:

Class 1 Customers; makes up $40 \%$ of all female customers of KOTON as shown in Table 4 and all are young customers between the ages of 16-34 as shown in Appendix 4. The youngest customers in the 16-17 age group make up 14\% of this class, which is the highest rate compared to the other classes. The following results regarding the fashion orientation as shown in Appendix 2 are reached. $80 \%$ of Class 1 customers; beliefs in the importance of being well dressed and that it is a reflection of one's thought and that being well-dressed is part of good 
life leading. Again, for $83 \%$ of these customers, dressing up is a necessity for getting ahead. Since all those statements is parts of the importance of being well-dressed, it can be said that Class 1 consists of customers that believe the importance of being well-dressed. $66 \%$ of Class 1 customers are buying at least one outfit of the latest fashion and $65 \%$ are in need of a variety of clothes due to their active lifestyle. Those statements belong to the fashion interest. It can be stated that Class 1 customers are interested in fashion even if they are not very intensive when a general fashion assessment is made. However, it can be argued that Class 1 customers are away from the concept of fashion leadership, because it is not important to be a fashion leader for $82 \%$, while $87 \%$ do not want to be one of the first to try fashion trends and $82 \%$ stated that they are not regarded as a leader in fashion. Moreoever, as shown in Appendix 3, the lifestyle of the $72 \%$ of the Class 1 customers is "Strivers." Those who are affiliated with the lifestyle called Strivers are trendy and fun-loving people, have arbitrarily low incomes, tend to be restricted in their interests and prefer stylish products that mimic the purchases of people with more financial means. When these features are taken into account, Class 1 can be described as " $A$ class that is young-aged, far from being a fashion leader but fashionable, attaches importance to be well-dressed and having a striver lifestyle." It may be a good marketing strategy for this class to prepare collections for customers that are both stylish, affordable and able to be used in business life. On the other hand, for customers in the 16-17 age group, still more affordable but more trendy collections can be more noticeable.

Class 2 Customers; makes up 25\% of all female customers of KOTON as shown in Table 4 and $80 \%$ are young customers between the ages of 16-34 as shown in Appendix 4. This is the highest rate after Class 1. The following results regarding the fashion orientation as shown in Appendix 2 are reached. In all of Class 2 customers, 92\% stated that they could recognize fashion trends, $91 \%$ stated that the clothes are one of the ways of expressing themselves, $88 \%$ stated that they wanted to be one of the first to try fashion trends and $86 \%$ stated that they most people regard themselves as the fashion leader. These ratios for fashion leadership are the highest ratios compared to the other classes, and it can be said that the customers of this class have a high hold on fashion leadership attitude. $88 \%$ of the Class 2 customers needed a variety of clothes because of their active lifestyle, $84 \%$ had at least one outfit for the latest fashion, $69 \%$ were usually reading fashion magazines / blocks, and $72 \%$ stated that they allocate time for fashion activities. These expressions of fashion interest appear to be the highest among all classes. Being well-dressed is important for $97 \%$ of customers in this class, apperal is reflection of one's own thoughts for 94\%, being well-dressed is a part of good life leading for 93\%, and for $92 \%$, being well-dressed is necessary to get ahead. These ratios, which are quite high, are the expression of the importance of well-dressed and are higher than the other classes. Moreover, as shown in Appendix 3; among all Class 2 customers, 39\% are strivers, 22\% are experienced, $18 \%$ are believers and $14 \%$ are achievers. Class 2 can be described as "A class with a very high fashion orientation in general," by taking all these features into account. The collections of the latest trend products for the customers in this class will be noteworthy. In terms of achieving customer awareness, advertising of these collections in up-to-date fashion magazines/blocks and fashion-related activities can be a positive marketing strategy.

Class 3 Customers; makes up 23\% of all female customers of KOTON as shown in Table 4 and 55\% are customers between the ages of 35-44 and 30\% are between the ages 45-50 
as shown in Appendix 4. For all of the statements related to being a fashion leader, the great likelihood of class customers has responded negatively (e.g, only $9 \%$ of the class participated in the expression "I want to be the first person to try fashion trends." in Appendix 2.) Compared with the other classes, it can be stated that the class is the most negative opinion holders regarding being a fashion leader in general. When Appendix 2 is examined, the following results are also reached regarding the fashion orientation: Attitudes towards fashion interest appear to be low in participation rates. About half of the members of this class agreed with two of the expressions about fashion interest $(60 \%$ of the class indicated that they needed various clothes due to the active lifestyle, $53 \%$ said they bought at least one outfit of the latest fashion, but the majority of customers in this class did not agree with the other two expressions. However, for Class 3 customers; being well-dressed is important for $83 \%$, being well-dressed is necessary for getting ahead according to $91 \%$, for $95 \%$ attire is a reflection of one's own thoughts and being well-dressed is a part of good life leading for $78 \%$. All of these statements are about the importance of being well-dressed, and it seems important to be well-dressed for Class 3 customers as their participation rates are high. Moreover, as shown in Appendix 3,59\% of the Class 3 customers' lifestyle is made up of believers. Since he general characteristics of people in the lifestyle described as believers are overly traditional, rule-bound, authoritarian and conservative, it is known that they prefer familiar products and established brands. When all these features are taken into account, Class 3 can be described as "A class that is middleaged, traditional, far from being a fashion leader and fashion interest but considers being well-dressed important." For this class of customers, it can be considered a good marketing strategy to consistently present samples of more classic models in the store. It may be a good opportunity for this class of customers to think that KOTON always has a classical piece that suits them, creating a dependency on the brand.

Class 4 Customers; makes up $11 \%$ of all female customers of KOTON as shown in Table 4 and $47 \%$ are customers between the ages of 25-34 and 30\% are between the ages 3544 as shown in Appendix 4. The following results regarding the fashion orientation as shown in Appendix 2 are reached: For this class of customers; being well-dressed does not matter for $59 \%$, being well-dressed is not a requirement for getting ahead for $76 \%$, attire is not a reflection of one's own thoughts for $74 \%$ and being well-dressed is not part of good life leading for $57 \%$. Many of these class customers express negative opinions against these statements about the importance of being well-dressed. While the majority of the other three classes show a positive attitude to the importance of being well-dressed, Class 4 exhibits a negative attitude towards it. $61 \%$ of the customers do not buy at least one outfit of the latest fashion, but $70 \%$ stated that it is important to be a fashion leader. Unlike the other three classes, the majority of Class 4 customers do not have an anti-fashion stance (57\% do not believe that fast fashion clothing gets more money from customers and $60 \%$ prefer to buy current fashion products instead of their favorite clothes). Moreover, as shown in Appendix 3,46\% of Class 4 customers are believers, $23 \%$ are strivers, and $20 \%$ are achievers. From the point of view of lifestyles, it is seen that the customers in this class are both those who love fashion and amusement, traditional and low-income, but also those who avoid change and love to show quality products to their peers. It is observed that this class, which constitutes the smallest ratio with $11 \%$ of the brand, does not show consistency in fashion orientation in general. Given all these features, Class 4 can be described as "A class that does not care about being well-dressed, is not anti-fashion, 
and is generally inconsistent with fashion orientation." For this class of customers, a guided marketing strategy may be appropriate. To promote the products to the well-known people followed by the customers and to make it easier for the customers to reach these products can be thought of as a strategy suitable for this class.

\section{Conclusion}

According to the analysis results, female customers of KOTON brand that operates as a fast-fashion retailer in Turkey as well as in the world is seen as divided into 4 classes according to their preferences of fashion orientation and lifestyle. These classes are defined as; "A class that is young-aged, far from being a fashion leader but fashionable, attaches importance to be well-dressed and having a striver lifestyle", "A class with a very high fashion orientation in general", "A class that is middle-aged, traditional, far from being a fashion leader and fashion interest but considers being well-dressed important" and "A class that does not care about being well-dressed, is not anti-fashion, and is generally inconsistent with fashion orientation". For each class, preferences of customers in terms of fashion orientation and lifestyle are interpreted in detail and suggestions of marketing strategies suitable for these preferences are presented. When the literature is examined, it is noteworthy that the Latent Class Analysis has not been applied in fast fashion. In this study, Latent Class Analysis is proposed as an alternative method to study customer segmentation, especially in the ready-made garment / fast fashion field.

\section{References}

Arıcıgil, Ç., Çiğdem. (2014). Latent class analysis for measuring Turkish people's future expectations for Turkey. Journal of Applied Statistics, 41, 519-529.

Bartholomew, D., Knott, M., \& Moustaki, I. (2011). Latent variable models and factor analysis: A unified approach.3th editon. West Sussex: John Wiley\&Sons, Ltd.

Byun, S-E., \& Sternquist, B. (2008). The antecedents of in-store hoarding: Measurement and application in the fast fashion retail environment. The International Review of Retail, Distribution and Consumer Research, 18(2), 133-147.

Cassill, N. L., \& Drake, M. F. (1987). Apparel selection criteria related to female consumers' lifestyle. Clothing \& Textiles Research Journal, 6(1), 20-28.

Collins, L. M., \& Lanza, S. T. (2010). Latent class and latent transition analysis: With applications in the social, behavioral, and health sciences. Hoboken, New Jersey: Wiley\&Sons, Inc.

Darley, W. K., \& Johnson, D. M. (1993). Effects of female adolescent locus of control on shopping behavior, fashion orientation and information search. International Review of Retail, Distribution and Consumer Research, 3(2), 149-165.

Gam, H. J. (2011). Are fashion-conscious consumers more likely to adopt eco-friendly clothing? Journal of Fashion Marketing and Management, 15(2), 178-193.

Goodman, L. A. (1974). Exploratory latent structure analysis using identifiable and unidentifiable models. Biometrika, 61(2), 215-231.

Gutman, J., \& Mills, M. K. (1982). Fashion style, self-concept, shopping orientation, and store patronage: An integrative analysis. Journal of Retailing, 64-89.

Hagenaars, J. A. (1993). Loglinear models with latent variables series: Quantitative applications in the social sciences. USA: Sage Publications. 
Hamşığlu, A. B. (Summer 2013). Fast food ürünleri satın alan tüketicilerin yaşam tarzlarını belirlemeye yönelik bir uygulama. International Journal of Economic and Administrative Studies, 11, 17-34.

Hawkins, D. I., Mothersbaugh, D. L., \& Mookerjee, A. (2010). Consumer behavior: Building marketing strategy. 11th edition. New Delhi: Tata McGraw Hill Education Private Limited.

Harp, S. S., Hlavaty, V., \& Horridge, P. E. (2000). South Korean female apparel market segments based on store attributes. Journal of Retailing and Consumer Services, 7, 161-170.

Hoyer, W. D., \& MacInnis, D. J. (2009). Consumer behavior. 5th edition. Belmond: Cengage Learning.

Jina, P. (2010). Consumption behavior and fashion orientation for luxury brands of Japanese and Korean consumers. Journal of Fashion Business, 14(3), 20-34.

Jones, S. J. (2009). Moda tasarımı. (Çev. H. Kılıç). İstanbul: Güncel Yayıncılık.

Kankaraš, M. (2010). Essays on measurement equivalence in cross-cultural survey research: A latent class approach (Doctoral dissertation). Retrieved from Tilburg University Research Portal.

Magidson, J., \& Vermunt, J. K. (2004). Latent class model. In D. Kaplan (Ed.), The sage handbook of quantitative methodology for the social sciences (pp. 175-198). USA: Sage Publications.

McCutcheon, A. (1987). Latent class analysis. USA: Sage Publications, Inc.

McCutcheon, A., \& Colins, M. (1998). Categorical data analysis: Log-linear and latent class models. In E. Scarbrough \& E. Tanenbaum (Eds). Research strategies in the social sciences: A guide to new approaches (pp. 71-95). US: Oxford University Press.

McCutheon, A. (2002). Basic concept and procedures in single- and multiple-group latent class analysis. In J. A. Hagenaars \& A. Mccutcheon (Eds.). Applied latent class analysis (55-85). US: Cambridge University Press.

Neves, B. B., \& Fonseca, J. R.S. (2015). Latent class models in action: Bridging social capital \& internet usage. Social Science Research, 50, 15-30.

Odabaşı, Y., \& Barış, G. (2003). Tüketici davranışı. 3rd edition. İstanbul: Media Cat.

Park, H., \& Burns, L. D. (2005). Fashion orientation, credit card, and compulsive buying. Journal of Consumer Marketing, 22(3), 131-141.

Preez, R. D. (2003). Apparel shopping behaviour - part 1: Towards the development of a conceptual theoretical model. SA Journal of Industrial Psychology, 29(3), 11-14.

Preez, R D., \& Visser, E. (2003). Apparel shopping behaviour - part 2: Conceptual theoretical model, market, segmets, profiles and implications. SA Journal of Industrial Psychology, 29(3), 15-20.

Preez, R. D., Visser, E., \& Zietsman, L. (2007). Profiling male apparel consumers: Lifestyle, shopping orientation, patronage behaviour and shopping mall behaviour, Management Dynamics, 16(1), $2-19$.

Shim, S., \& Kotsiopulos, A. (1993). A typology of apparel shopping orientation segments among female consumers. Clothing and Textiles Research Journal, 12(73), 73-85.

Tungate, M. (2006). Modada marka olmak: Armani'den Zara'ya moda devlerinin marka oluşturma tarzları. (Trans. G. Günay). İstanbul: Rota Yayınları.

Vermunt, J. K. (1996). Log-linear models for event histories. USA: Sage Publications.

Yeşiloğlu, H. (2013). Yaşam tarzının müşsteri sadakati ve tüketicilerin satın alma davranışları üzerine etkileri: Organik gıda ürünlerini kullanan tüketiciler üzerinde bir uygulama. (Master dissertation). Retrieved from Council of Higher Education (327465).

Walker, J., \& Almond, P. (2010). Interpreting statistical findings: A guide for health professionals and student. England: Open University Press. 
Watson, L. (2007). Modaya yön verenler. (Çev. G. Ayas) İstanbul: Güncel Yayıncılık.

Wu, S. I. (2013). The relationship between consumer characteristics and attitude toward online shopping. Marketing Intelligence \& Planning, 21(1), 37-44.

Zarley, M. (2010). An exploratory investigation of the decision processes and psychographic characteristics of fast versus slow fashion consumers (Master dissertation). Retrieved from Colorado State University.

Zietsman, L. (2006). Profiling male apparel consumers: Demographic characteristics, lifestyle, shopping orientation, patronage behaviour and shopping mall behaviour (Master dissertation). Retrieved from SUNScholar Research Repository. 
Appendix 1: Covariates and Indicators Used in The Model

\begin{tabular}{|c|c|c|c|}
\hline \multirow{2}{*}{$\begin{array}{l}\text { Variable } \\
\text { Demographic Variables }\end{array}$} & \multicolumn{3}{|c|}{ Categories } \\
\hline & & & \\
\hline \multirow{2}{*}{$\begin{array}{ll}\text { Age } & 1: 16-17 \\
\text { SFS }\end{array}$} & $3: 25-34$ & 4: $35-44$ & $5: 45-50$ \\
\hline & 2: B & 3: $\mathrm{C} 1$ & 4: $\mathrm{C} 2$ \\
\hline Marital Status & 2: Married & 3: Divorced & 4: Widow \\
\hline \multicolumn{4}{|l|}{ Psychographic Variables } \\
\hline \multicolumn{4}{|l|}{ Fashion Orientation } \\
\hline \multicolumn{2}{|c|}{ It is important for me to be a fashion leader. } & 1: Yes & 2: No \\
\hline \multicolumn{2}{|c|}{ I am confident in my ability to recognize fashion trends. } & 1: Yes & 2: No \\
\hline \multicolumn{2}{|c|}{ I want to be one of the first to try fashion trend. } & 1: Yes & 2: No \\
\hline \multicolumn{2}{|c|}{$\begin{array}{l}\text { I am the first to try new fashion; therefore, many people regard } \\
\text { me as being a fashion leader. }\end{array}$} & 1: Yes & 2: No \\
\hline \multicolumn{2}{|c|}{$\begin{array}{l}\text { Clothes are one ofe the most important way I have of } \\
\text { expressing my individuality. }\end{array}$} & 1: Yes & 2: No \\
\hline \multicolumn{2}{|c|}{ Because if my active lifestyle, I need a wide variety of clothes. } & 1: Yes & 2: No \\
\hline \multicolumn{2}{|c|}{ I always buy at least one outfit of the latest fashion. } & 1: Yes & 2: No \\
\hline \multicolumn{2}{|c|}{ I always read fashion magazines/blogs. } & 1: Yes & 2: No \\
\hline \multicolumn{2}{|c|}{ I spend a lot of time on fashion related activities. } & 1: Yes & 2: No \\
\hline \multicolumn{2}{|l|}{ It's important to be well-dressed. } & 1: Yes & 2: No \\
\hline \multicolumn{2}{|c|}{ If you want to get ahead, you have to dress the part. } & 1: Yes & 2: No \\
\hline \multicolumn{2}{|c|}{ What you think of yourself is reflected by what you wear. } & 1: Yes & 2: No \\
\hline \multicolumn{2}{|c|}{ Wearing good clothes is part of leading the good life. } & 1: Yes & 2: No \\
\hline \multicolumn{2}{|c|}{ I resent being told what to wear by so-called fashion experts. } & 1: Yes & 2: No \\
\hline \multicolumn{2}{|c|}{$\begin{array}{l}\text { Fast fashion clothing is just a way to get more money from the } \\
\text { consumer. }\end{array}$} & 1: Yes & 2: No \\
\hline \multicolumn{2}{|c|}{ I buy clothes I like regardless of the current fashion. } & 1: Yes & 2: No \\
\hline \multicolumn{4}{|l|}{ Lifestyle } \\
\hline \multirow{2}{*}{ Lifestyle } & 2: Believers & 3: Achievers & 4: Strivers \\
\hline & 5:Experiencers & 7: Survivors & \\
\hline
\end{tabular}




\section{Appendix 2: Conditional Probabilities of Variables Related to Fashion Orientation}

\begin{tabular}{|c|c|c|c|c|c|}
\hline \multirow[b]{2}{*}{ Variables } & \multirow[b]{2}{*}{ Cat. } & \multicolumn{4}{|c|}{ Clusters } \\
\hline & & 1 & 2 & 3 & 4 \\
\hline \multirow{2}{*}{ It is important for me to be a fashion leader. } & Yes & 0,1835 & 0,7799 & 0,2243 & 0,7034 \\
\hline & No & 0,8165 & 0,2201 & 0,7757 & 0,2966 \\
\hline \multirow{2}{*}{$\begin{array}{l}\text { I am confident in my ability to recognize fashion } \\
\text { trends. }\end{array}$} & Yes & 0,3463 & 0,9201 & 0,3325 & 0,6363 \\
\hline & No & 0,6537 & 0,0799 & 0,6675 & 0,3637 \\
\hline \multirow{2}{*}{ I want to be one of the first to try fashion trend. } & Yes & 0,1265 & 0,8855 & 0,0938 & 0,4945 \\
\hline & No & 0,8735 & 0,1145 & 0,9062 & 0,5055 \\
\hline \multirow{2}{*}{$\begin{array}{l}\text { I am the first to try new fashion; therefore, many } \\
\text { people regard me as being a fashion leader. }\end{array}$} & Yes & 0,1834 & 0,8684 & 0,1265 & 0,6137 \\
\hline & No & 0,8166 & 0,1316 & 0,8735 & 0,3863 \\
\hline \multirow{2}{*}{$\begin{array}{l}\text { Clothes are one of the most important ways I } \\
\text { have of expressing my individuality. }\end{array}$} & Yes & 0,7122 & 0,912 & 0,5887 & 0,454 \\
\hline & No & 0,2878 & 0,088 & 0,4113 & 0,546 \\
\hline \multirow{2}{*}{$\begin{array}{l}\text { Because if my active lifestyle, I need a wide } \\
\text { variety of clothes. }\end{array}$} & Yes & 0,6474 & 0,8824 & 0,6082 & 0,3574 \\
\hline & No & 0,3526 & 0,1176 & 0,3918 & 0,6426 \\
\hline \multirow{2}{*}{$\begin{array}{l}\text { I always buy at least one outfit in the latest } \\
\text { fashion. }\end{array}$} & Yes & 0,6632 & 0,8371 & 0,529 & 0,3897 \\
\hline & No & 0,3368 & 0,1629 & 0,471 & 0,6103 \\
\hline \multirow{2}{*}{ I always read fashion magazines/blogs. } & Yes & 0,4091 & 0,6947 & 0,3199 & 0,5147 \\
\hline & No & 0,5909 & 0,3053 & 0,6801 & 0,4853 \\
\hline \multirow{2}{*}{ I spend a lot of time on fashion-related activities. } & Yes & 0,3047 & 0,7247 & 0,2221 & 0,6435 \\
\hline & No & 0,6953 & 0,2753 & 0,7779 & 0,3565 \\
\hline \multirow{2}{*}{ It's important to be well-dressed. } & Yes & 0,8045 & 0,9681 & 0,8316 & 0,4081 \\
\hline & No & 0,1955 & 0,0319 & 0,1684 & 0,5919 \\
\hline \multirow{2}{*}{$\begin{array}{l}\text { If you want to get ahead, you have to dress the } \\
\text { part. }\end{array}$} & Yes & 0,8358 & 0,9189 & 0,908 & 0,2381 \\
\hline & No & 0,1642 & 0,0811 & 0,092 & 0,7619 \\
\hline \multirow{2}{*}{$\begin{array}{l}\text { What you think of yourself is reflected in what } \\
\text { you wear. }\end{array}$} & Yes & 0,8049 & 0,9417 & 0,9459 & 0,2605 \\
\hline & No & 0,1951 & 0,0583 & 0,0541 & 0,7395 \\
\hline \multirow{2}{*}{$\begin{array}{l}\text { Wearing good clothes is part of leading the good } \\
\text { life. }\end{array}$} & Yes & 0,8081 & 0,9313 & 0,7809 & 0,4259 \\
\hline & No & 0,1919 & 0,0687 & 0,2191 & 0,5741 \\
\hline \multirow{2}{*}{$\begin{array}{l}\text { The fast fashion clothing is just a way to get } \\
\text { more money from the consumer. }\end{array}$} & Yes & 0,6345 & 0,6368 & 0,735 & 0,4245 \\
\hline & No & 0,3655 & 0,3632 & 0,265 & 0,5755 \\
\hline \multirow{2}{*}{$\begin{array}{l}\text { I buy clothes I like regardless of the current } \\
\text { fashion. }\end{array}$} & Yes & 0,7319 & 0,8487 & 0,7773 & 0,3997 \\
\hline & No & 0,2681 & 0,1513 & 0,2227 & 0,6003 \\
\hline
\end{tabular}


Appendix 3: Conditional Probabilities of Lifestyle Variable

\begin{tabular}{ccccc}
\hline & \multicolumn{5}{c}{ Clusters } \\
\hline Categories & $\mathbf{1}$ & $\mathbf{2}$ & $\mathbf{3}$ & $\mathbf{4}$ \\
\hline Thinker & 0 & 0 & 0,0561 & 0,0001 \\
\hline Believer & 0,0005 & 0,1847 & 0,5938 & 0,4612 \\
\hline Achiever & 0,1673 & 0,14 & 0,1733 & 0,2001 \\
\hline Striver & 0,716 & 0,3917 & 0,0011 & 0,2368 \\
\hline Experiencer & 0,116 & 0,2189 & 0,0003 & 0,0006 \\
\hline Maker & 0,0002 & 0,0557 & 0,1661 & 0,1012 \\
\hline Survivor & 0 & 0,0089 & 0,0094 & 0
\end{tabular}

Appendix 4: Conditional Probabilities of Age Variable

\begin{tabular}{ccccc}
\hline & \multicolumn{5}{c}{ Clusters } \\
\hline Categories & $\mathbf{1}$ & $\mathbf{2}$ & $\mathbf{3}$ & $\mathbf{4}$ \\
\hline $16-17$ & 0,1414 & 0,1221 & 0 & 0,0036 \\
\hline $18-24$ & 0,4642 & 0,4062 & 0,0001 & 0,1148 \\
\hline $25-34$ & 0,3942 & 0,2774 & 0,1555 & 0,4745 \\
\hline $35-44$ & 0 & 0,1293 & 0,5481 & 0,3041 \\
\hline $45-50$ & 0,0001 & 0,0651 & 0,2962 & 0,103 \\
\hline
\end{tabular}

